\title{
PENGEMBANGAN PARIWISATA KOTA BIMA SEBAGAI DAERAH TRANSIT WISATA ALTERNATIF
}

\author{
Syarif Ahmad \\ Administrasi Negara, Sekolah Tinggi Ilmu Sosial dan Ilmu Politik (STISIP) Mbojo ${ }^{1)}$ \\ Email: syarif@stipsipbima.ac.id \\ Adi Hidayat Argubi \\ Administrasi Negara, Sekolah Tinggi Ilmu Sosial dan Ilmu Politik (STISIP) Mbojo ${ }^{1)}$ \\ Email : adi.hidayat@stisipbima.ac.id
}

\begin{abstract}
ABSTRAK
Kota Bima memiliki potensi yang besar dan berpeluang dikembangkan sebagai salah satu Daerah Tujuan Wisata (DTW) di NTB bagian timur. Potensi pariwisata yang melimpah tersebut berupa potensi alam dan budaya yang berkembang di masyarakat Kota Bima. Tujuan penelitian ini adalah ingin mengkaji potensi dan daya dukung yang dimiliki dan ingin menemukan strategi pengembangan pariwisata yang tepat untuk menjadikan Kota Bima sebagai daerah wisata transit alternativedan prospek pengembangan pariwisata di Kota Bima.

Populasi dalam penelitian ini adalah wisatawan yang berkunjung diobjek-objek wisata unggulan di Kota Bima. Teknik pengambilan sampel wisatawan digunakan cara Quota Sampling Method yaitu cara pengambilan sampel yang telah ditentukan /dijatah sebelumnya. Teknik pengumpulan data yaitu menggunakan teknik observasi, wawancara berstruktur, kuesioner dan studi literatur. Teknik analisis data yang digunakan adalah deskriptif kualitatif, dan SWOT.

Berdasarkan penelitian pengembangan pariwisata Kota Bima sebagai daerah transit wisata alternativedapat disimpulkan bahwa : 1). Sarana dan prasarana pariwisata di Kota Bima meliputi sarana kesehatan, transportasi, air bersih, energi, perbankan, pos, telekomunikasi, dan usaha sarana dan jasa pariwisata serta potensi daya tarik wisata di Kota Bima yang melimpah; 2). Strategi pengembangan pariwisata Kota Bima sebagai daerah transit wisata alternatif terdapat dua yaitu strategi umum dan strategi alternatif. Strategi umum meliputi: strategi pengembangan dan penetrasi pangsa pasar dan pengembangan produk wisata. Adapun strategi alternatif meliputi: pengembangan daya tarik wisata di Kota Bima, peningkatan keamanan, pengembangan prasarana dan sarana pariwisata, promosi, perencanaan dan pengembangan pariwisata berkelanjutan dan berbasis kerakyatan, serta pengembangan sumber daya manusaia kepariwisataan dan lembaga pariwisata; 3). Program-program yang dirancang untuk pengembangan Kota Bima sebagai daerah tujuan wisata meliputi: program penyusunan blok kawasan, program pengembangan produk wisata, program inventarisasi daya tarik wisata, program peningkatan keamanan melalui Sistem Keamanan Lingkungan (Siskamling), pembangunan hotel berbintang, meningkatkan akses ke Kawasan Kolo, rencana pengembangan sarana wisata tirta, penyediaan fasilitas toilet dan kamar mandi umum, penyediaan ruang terbuka (open space), memperluas pangsa pasar, melakukan promosi melalui Biro Perjalanan Wisata, melakukan promosi melalui internet dan media lainnya, mendirikan TIC (Tourism Information Centre), melaksanakan pentas kebudayaan,pelestarian nilai sosial budaya, pemberdayaan masyarakat, membentuk lembaga pengelolaan daya tarik wisata, meningkatkan kualitas SDM pariwisata, serta mengadakan kampanye sadar wisata dan sosialisasi sapta pesona.
\end{abstract}

Kata kunci: Tourism Development ; Tourism Transit 


\section{PENDAHULUAN}

\subsection{Latar Belakang Masalah}

Potensi keindahan alam serta popularitas Kota Bima yang telah lama terbentuk di kancah kepariwisataan nasional maupun internasional serta didukung oleh faktor lokasi yang sangat strategis dan aksessibilitas di jalur arteri primer lintas Sumbawa-Flores - Pulau Komodo. Sesungguhnya Kota Bima memiliki potensi yang besar dan berpeluang dikembangkan sebagai salah satu Daerah Wisata Transit Alternatif (DTW) di NTB wilayah Timur. Akan tetapi pengelolaan daerah sebagai transit wisata dengan destinasi Pulau Komodo menjadi alternatif wisata yang dapat meningkatkan penerimaan daerah Kota Bima. Potensi pariwisata yang melimpah tersebut berupa potensi alam dan budaya yang berkembang di masyarakat Kota Bima hampir tidak ditemui di daerah lain di Indonesia. Kota Bima memiliki banyak kekhasan yang menjadi modal utama pengembangan pariwisata suatu daerah, seperti keberadaan suku Bima "Sambori" asli yang merupakan masyarakat asli Kota Bima yang mempunyai bahasa dan adat istiadat yang sangat unik, seperti upacara Ntumbu (adu kepala), Gantao, Kareku Kandei, Rawa Mbojo, Hadra, upacara Ua Pua dan lain-lain. Kota Bima juga memiliki kedekatan kawasan dengan kawasan Taman Nasional Komodo yang menjadi destinasi pariwisata dunia.

Seharusnya pengelolaan kawasan

Kota Bima dengan potensi pariwisata yang melimpah ini seharusnya telah mampu menghantarkan kawasan ini sebagai salah satu alternatif transit wisata di NTB wilayah timur, namun permasalahannya adalah bahwa realitas yang ada menunjukkan bahwa pengelolaan objek-objek wisata diKota Bima oleh pemerintah daerah selama ini ternyata hanya mampu mempertahankan kawasannya ini sebagai kawasan transit wisata menuju Pulau Komodo yang belum terkelola baik. Potensi pariwisata di Kota
Bima apabila dikembangkan menjadi transit wisata alternatif maka akan memberikan kontribusi pada Pendapatan Asli Daerah (PAD), peningkatan kesejahteraan dan ekonomi masyarakat, terbukanya kesempatan berusaha, serta mengurangi jumlah angka pengangguran seiring dengan meningkatnya kunjungan wisatawan ke daerah tersebut. Untuk melihat belum optimalnya pengelolaan potensi wisata di Kota Bima dapat dilihat pada data tingkat kunjungan wisatawan di Kota Bima. Data kunjungan menunjukkan bahwa tingkat kunjungan wisatawan ke Kota Bima pada tahun 2010 sebesar 255.584, 2011 sebesar 285.114, 2012 sebesar 211.374, 2013 sebesar 278.423, 2014 sebesar 296.421 wisatawan nusantara dan mancenegara. Tingkat kunjungan ini akan meningkat dengan pengelolaan dan pengembangan pariwisata yang baik.

Selain potensi pariwisata yang besar, Kota Bima memiliki keunggulan komparatif dan kompetitif dibanding daerah lain, yaitu menjadi jalur utama yang menghubungkan pulau Sumbawa dengan salah satu destinasi pariwisata, yaitu Pulau Komodo. Keunggulan pada aspek ini harus mampu dimanfaatkan dengan baik oleh pemerintah Kota Bima, yaitu mengembangkan Kota Bima sebagai kota wisata transit alternatif sebelum wisatawan menuju Wisata Komodo.

Kota Bima dapat menjadi destinasi alternatif sebelum menuju Pulau Komodo karena didukung oleh berbagai objek wisata unggulan, misalnya, Objek Wisata Pantai Kolo, Pantai Ule, Lawata, Ama Hami, Istana Musium ASI Mbojo, Dana Traha, Pulau Kambing, Uma Lengge, Pantai Ni'u dan sebagainya yang memungkinkan adanya suatu paket wisata Kota Bima untuk menghindari kejenuhan wisatawan. Selain memiliki kekayaan alam yang dapat menunjang kegiatan pariwisata, Pantai juga didukung oleh beragam potensi budaya lokal seperti kegiatan tradisional upacara adat U'a Pua, 
Festival Wisata Asakota, Kareku Kandei, Hadra, Gantao, Tarian Wura Bongi Monca, Muna Tembe dan sebagainya, menjadikan Kota Bima memiliki nilai tambah sebagai primadona wisata di wilayah timur NTB yang tidak akan kita jumpai di daerah lain di ditanah air. Oleh karena itu, dalam rangka menjadikan Kota Bima sebagai transit wisata alternatif, tentu diperlukan keberanian dan langkah strategis dengan memaksimalkan seluruh potensi Kota Bima agar Kota Bima tetap eksis dalam dunia kepariwisataan. Kalau selama ini banyak para wisatawan melewati Kota Bima untuk tujuan wisata ke Pulau Komodo hanya melewati Kota Bima, maka pemerintah daerah harus menangkap peluang pengembangan pariwisata transit untuk mempepanjang homestay wisatawan yang akan menuju ke Pulau Komodo di Kota Bima sehingga dapat meberikan kontribusi bagi PAD Kota Bima.

Penjelasan yang terurai di atas merupakan pengkajian dokumen yang normatif dan hal lain yang melatarbelakangi penelitian ini adalah bahwa sampai saat ini belum ada studi maupun kajian ilmiah, khususnya di Kota Bima tentang kajian pengembangan wisata transit sebagai alternatif, sehingga hal ini sangat penting bagi penulis untuk mengambil topik penelitian "Pengembangan Pariwisata Kota Bima Sebagai Daerah Transit Wisata Alternatif."

\subsection{Tujuan Penelitian}

Tujuan penelitian ini adalahIngin mengkaji potensi dan daya dukung yang dimiliki Kota Bima untuk dapat dikembangkan menjadi salah satu destinasi wisata transit alternatif ;

Ingin menemukan strategi pengembangan pariwisata yang tepat untuk menjadikan Kota Bima sebagai daerah wisata transit alternative; dan Ingin menganalisa prospek pengembangan pariwisata di Kota Bima sebagai wisata transit alternatif di masa sekarang dan akan datang dilihat dari aspek permintaan dan penawaran.

\section{TINJAUAN PUSTAKA}

\subsection{Potensi Pariwisata Sebagai Penawaran dan Permintaan}

Unsur yang berupa potensi pariwisata sangat beragam, menurut Wahyudi (2003:43) mengatakan bahwa unsur potensi pariwisata terdiri dari;

1). Benda-benda yang disediakan dan terdapat di alam (Natural Amenities) yang meliputi : iklim, lansekap, pemandangan alam/panorama,hutan balukar,flora dan fauna, Health Center, dan sebagainya.

2). Hasil ciptaan manusia (made man supply) meliputi monemen/bangunan bersejarah, tempat-tempat ibadah,seni budaya,festival, dan sebagainya.

3). Prasarana (infrastructure) terdiri dari :

a. Prasana umum : Jalan raya,jembatan,bandara dan lain-lain.

b. Prasarana kebutuhan masyarakat banyak : rumah sakit, tourism Information Center, bank, kantor pos, dan sebagainya.

4). Sarana Kepariwisataan (Tourism suprastructure) terdiri dari:

a. Sarana pokok kepariwisataan akomodasi, transportasi, Tour \& Travel, objek wisata). Sarana pelengkap pariwisata (fasilitas rekreasi, fasilitas olah raga, dan sebagainya).

b. Sarana penunjang pariwsata (kerajinan rakyat, Night Club, dan sebagainya)

5). Pola Hidup masyarakat (the people's way of life) yang dapat berupa adat istiadat/tradisi yang berlaku pada suatu masyarakat juga tak luput dari potensi pariwisata yang ditawarkan.

Sedangkan permintaan (demand) pariwisata terdiri dari bermacam- 
macam unsure yang tidak hanya berbeda sifat dan bentuknya antara satu sama lain, tetapi juga manfaat dan kegunaannya bagi wisatawan. Ini dikarenakan produk industri pariwisata terdiri dari berbagai produk yang meliputi semua jasa/service yang dibutuhkan wisatawan semenjak ia berangkat meninggalkan kediamannya, sampai ia kemKomodo ke rumah di mana ia tinggal. Oleh karena itu seorang wisatawan tidak mungkin hanya menkonsumsi satu produk/service selama melakukan perjalanan wisata, akan tetapi mutlak menkonsumsi beberapa macam produk/service dari perusahaan industri pariwisata yang berbeda-beda dan ditawarkan secara terpisah. Sehingga wisatawan membutuhkan Package of Service.

\subsection{Pendekatan Strategi Pengembangan Pariwisata}

Hasil simposium internasional tahun 2004 di Madrid, Spanyol tentang trend pariwisata dunia mencuatkan kecenderungan kuat untuk memobilisasi ke wisata pulau Komodo dari negaranegara di dunia kepada orisinalitas kealaman (natural originality) dan kesadaran manusia akan pelestarian sumber daya (the human awareness of sources conservation). Dan negara-negara produsen wisatawan (tourist producing countries) dan para wisatawan mereka selalu siap 'menyerbu' negara mana saja yang memiliki potensi alam lestari yang berkualitas (qualified), khas (unique) dan langka (scarce). Maka menurut Juhanda (2003:12-18) mengatakan bahwa "dalam pengembangan pariwisata daerah strateginya antara lain :

a. Mengenali potensi Pasar. Daerah harus mengenali secara akurat siapa pasar wisatawan kita, baik pasar riil maupun pasar potensial. Apakah beberapa objek dan daya tarik wisata di daerah dikunjungi secara konsisten oleh wisatawan dari daerah-daerah atau kota-kota lain? Kalau sudah, apakah jumlah mereka signifikan. Berapa persen dari mereka jika dibandingkan dengan wisatawan kita sendiri? Berapa besar pengeluaran rupiah mereka di objek-objek wisata, yang langsung dinikmati oleh masyarakat lokal, dan sebagainya? Deretan pertanyaan ini perlu diperpanjang lagi sehingga daerahdaerah tahu persis potensi pasar riil yang dimiliki. Singkatnya, kondisi pasar harus diteliti secara cermat sebelum memprioritaskan pengembangan objek dan daya tarik wisata serta menyediakan berbagai kebutuhan untuk para wisatawan.

b. Memberdayakan Sumber Daya Manusia dan Lembaga. Ada tiga aktor penting yang harus diberdayakan:

1). Government Agencies (seluruh elemen dalam hirarki pemerintahan, mulai dari atas sampai bawah, harus diberdayakan menuju sadar akan pariwisata dan siap menjadi host-community (tuan rumah penerima wisatawan). Daya kreasi tentang kepariwisataan bagi seluruh komponen di dalam lembaga pemerintahan harus diarahkan kepada tourism-minded.

2). Non-profit organisations (LSMLSM, pusat-pusat komunikasi publik, konsultan pariwisata, dan lain-lain) harus bersinergi kerja dengan kebijakan daerah tentang pengembangan pariwisata daerah.

3). Commercial enterprises (mereka adalah para pelaku bisnis di bidang pariwisata, pemilik modal dan pengakses sumber-sumber investasi). Kerjasama antar ketiga aktor ini secara terpadu, adil, transparan dan rasional, akan menghasilkan output yang optimal.

c. Menentukan Skala Prioritas Pengembangan. Sulit bagi daerahdaerah yang belum menjadi tujuan utama kunjungan wisatawan untuk 
menggerakkan seluruh potensi pengembangan objek dan daya tarik wisatanya secara global/general. Serba keterbatasan inilah yang mengharuskan daerah untuk memilih satu atau dua objek wisata unggulan untuk dikembangkan secara optimal. Kuncinya adalah bahwa daerah harus memiliki citra (image) dari objek wisata yang dikembangkan. Mencari dan menentukan tampilan berbeda (baik jenis objek wisata maupun iveniven daya tariknya) dengan daerahdaerah lain secara tegas. Pencitraan fisik dan non-fisik suatu daerah secara khas, berbasis pada budaya dan simbol-simbol lokal, akan mampu merekatkan masyarakat dengan pemerintah dan pariwisata itu sendiri.

d. Berbasis Pada Masyarakat (Community-based Tourism Development), dengan berpegang pada prinsip: Go to the people, live among the people, learn from the people, work with the people, start with what the people know, build on what the people have, teach by showing, learn by doing, not a showcase, but a pattern, not adds and ends, but a system, not piecemeal, but integrated approach, not to conform, but to transform, and not relief, but release.

Pengembangan pariwisata membutuhkan suatu perencanaan yang benar-benar matang agar dapat dilaksanakan secara tepat sasaran. Menurut Haryono (2003, 20): "Pegembangan pariwisata harus mampu mempertahankan keberlangsungan hidup (sustainability) sumber-sumber daya yang di milikinya baik sumber daya alam (natural resources) seperti panorama alam, kondisi topografi, flora dan fauna serta iklim maupun aneka sumberdaya budaya (cultural resources) yang berupa budaya fisik seperti artefak peninggalan sejarah maupun ciptaan kontemporer dan budaya non fisik (living culture)".
Setiawan (2004, 34) mempunyai pandangan yang berbeda mengenai pengembangan pariwisata, dia mengatakan bahwa: "Pengembangan pariwisata harus mampu memberikan pertumbuhan baik pertumbuhan lokal (local growth) pada level komunitas dan pertumbuhan secara menyeluruh."

Pusat Studi Pariwisata Universitas Gadjah Mada (Puspar UGM) (2003, 2426) memberikan beberapa pendekatan pengembangan pariwisata, yaitu:

a. Pendekatan Holistik dan Keterpaduan Perencanaan Intersektoral Dan Integral. Pendekatan holistik merupakan pendekatan menyeluruh dalam melakukan pembangunan, artinya meskipun perencanaan ini fokusnya adalah pariwisata namun pada hakekatnya tidak dapat di pisahkan dengan pembangunan lainnya. Perencanaan terpadu di butuhkan untuk menjamin adanya keterkaitan antar sektor dan aktor dalam suatu sistem pengembangan terpadu.

b. Pendekatan Pengembangan Pariwisata Berkelanjutan (Sustanable Tourism Development Approach. Pengembangan pariwisata berkelanjutan di dasarkan pada pendekatan bahwa pengembangan pariwisata nasional nantinya harus bertumpu pada kekuatan sendiri, dan bermuara pada terciptanya kemandirian bangsa Indonesia dalam mewujutkan ketahanan nasional.

c. Pendekatang Pengembangan Wilayah (Area Development Approach). Kegiatan pengembangan kepariwisataan pada suatu daerah akan merupakan daya tarik dan daya dorong bagfi berkembangnya masyarakat, daerah dan wilayah yang melingkupinya. Apapun, seberapa pun dan jenis yang bagaimana dari program-program pengembangan kepariwisataan yang dilakukan pada suatu daerah tertentu akan berpengaruh kepada sumberdaya 
manusia dan sumberdaya alam/lingkungan, maupun wilayah sekitarnya. Kemajuan kegiatan kepariwisataan akan mempengaruhi kemajuan kehidupan penduduk.

d. Pendekatan Pemberdayaan Masyarakat (Tourism Community Based Resources Development Approach). Pengembangan pariwisata hendaknya berperan dalam upaya pemberdayaan masyarakat. Pemerataan dan keseimbangan pemanfaatan ruang maupun program sektoral juga merupakan kriteria penting dalam pengembangan

Pariwisata. Keseimbangan pemanfaatan ruang dapat terjadi dengan pembagian wilayah pengembangan disertai dengan penentuan karakteristik pengembangan yang sesuai untuk masing-masing wilayah di Pariwisata. Sehingga diharapkan sektor pertanian dan perkebunan, jasa, perdagangan, serta kelautan dapat berinteraksi secara sinergis dengan berbagai sektor lain untuk meningkatkan kesejahteraan rakyat.

\section{Gambar 1. Pendekatan Pengembangan Kepariwisataan}

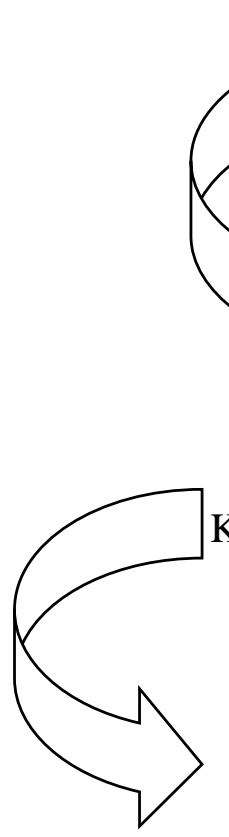

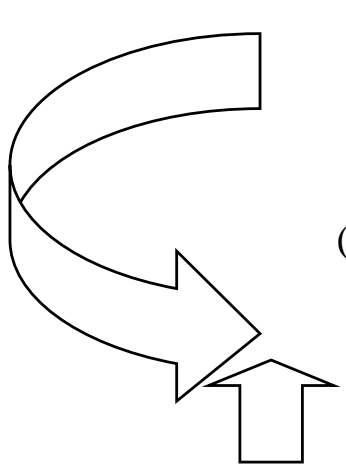

Lembaga Swadaya Masyarakat (LSM)

Kelompok Swadaya Masyarakat (KSM)

PENDEKATAN KEMASYARAKATAN

(Community Based)
PENDEKATAN

KERUANGAN/WILAYAH

(Spatial Based)

Pemerintah Kabupaten

Pemerintah Kec. / Desa

Swasta Lokal
Masyarakat Lokal

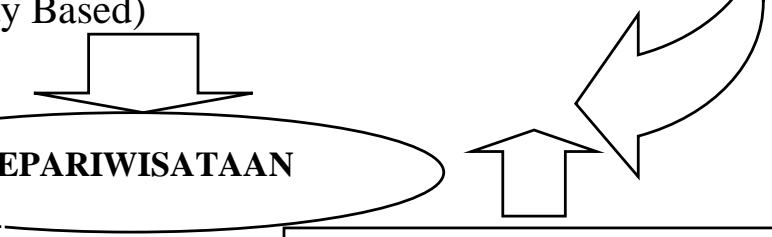

KEPARIWISATAAN
PENDEKATAN SEKTORAL (SECTORAL BASED)

Dinas Pariwisata

Dinas Kehutan

Dinas-Dinas Sektoral

Swasta Lokal

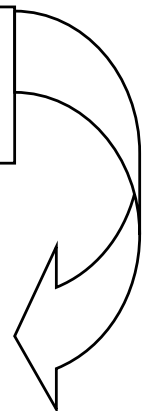

Sumber Data: Pusat Studi Pariwisata Universitas Gadjah Mada (Puspar UGM) (2003)

Dalam konteks wawasan baru, pengembangan sektor pariwisata di tuntut untuk mengarah pada terwujudnya tahapan pengembangan pariwisata yang berlanjut (sustainable tourism development) yang mengisyaratkan ketaatan pada prinsip-prinsip pengembangan pariwisata sebagai berikut (Wahyudi, 2003: 45):

a. Prinsip pengembangan yang berpijak pada aspek pelestarian dan berorientasi ke depan (jangka panjang), b. Penekanan pada nilai manfaat yang besar bagi masyarakat lokal,

c. Prinsip pengelolaan aset/sumberdaya yang tidak merusak,

d. Kesesuaian antara kegiatan pengembangan pariwisata dengan skala kondisi dan karakter suatu area yang akan di kembangkan,

e. Keselarasan dan sinergi antara kebutuhan wisatawan, lingkungan hidup dan masyarakat lokal, 
f. Antisipasi dan monitoring terhadap proses perubahan yang terjadi akibat pengembangan pariwisata,

g. Pembangunan harus didasari perencanaan dan di fokuskan untuk memperkuat potensi lokal,

h. Pengembangan pariwisata harus mampu mengembangkan apresiasi yang lebih peka dari masyarakat terhadap warisan budaya dan lingkungan hidup.

\subsection{Strategi Pemasaran Daerah Transit Wisata}

Dalam pengembangan pariwisata tidak terlepas dari bagaimana strategi pemasaran yang digunakan oleh pemerintah daerah untuk menjadikan Kota Bima sebagai daerah transit wisata alternatif. Strategi pemasaran merupakan juga action plan dari kegiatan pemasaran. Sehingga strategi pemasaran mempunyai kedudukan yang sangat penting dalam kemajuan. Pengertian strategi pemasaran menurut Assauri adalah: " rencana menyeluruh, terpadu dan menyatu di bidang pemasaran yang dapat memberikan panduan tentang kegiatan yang akan dijalankan untuk dapat tercapainya tujuan pemasaran suatu usaha"(1987).

Menurut J.Krippendorf (dalam Assauri, 1971) batasan tentang marketing dalam kepariwisataan adalah sebagai berikut: "Marketing in tourism to be understood as the systhematic and coordinated ececution of business policy by tourist undertaking wheter private or state owned at local, regional, national or international level to archieve the optional satisfaction of needs of identifiable consumer goods and in doing so to achive appropriate return".

Jika diterjemahkan secara bebas yang dimaksud dengan pemasaran pariwisata adalah suatu sistem dan koordinasi yang harus dilakukan sebagai kebijaksanaan bagi perusahaanperusahaan kelompok industri pariwisata, baik milik swasta atau pemerintah dalam ruang lingkup regional, nasional atau internasional untuk mencapai kepuasan wisatawan dengan memperoleh keuntungan yang wajar. Sedangkan menurut Wahab dalam Yoeti, adalah sebagai berikut: "Pemasaran Pariwisata adalah suatu proses manajemen yang dilakukan oleh organisasi pariwisata nasional atau perusahaan-perusahaan termasuk dalam kelompok industri pariwisata untuk melakukan identifikasi terhadap wisatawan yang sudah punya keinginan untuk melakukan perjalanan wisata dan wisata yang punya potensi akan melakukan oerjalanan wisata dengan jalan melakukan komunikasi dengan mereka, mempengaruhi keinginan, kebutuhan, memotivasinya terhdap apa yang dia sukai dan yang tidak disukainya, pada tingkat daerah-daerah local, regional, nasional ataupun internasional dengan menyediakn objek dan atraksi wisata agar wisatawan memperoleh kepuasan optimal. (2002)"

\section{METODE PENELITIAN}

Penelitian ini mengunakan metode deskriptif. Populasi dalam penelitian ini adalah wisatawan yang berkunjung diobjek-objek wisata unggulan di Kota Bima. Teknik pengambilan sampel wisatawan digunakan cara Quota Sampling Method yaitu cara pengambilan sampel yang telah ditentukan /dijatah sebelumnya. Teknik pengumpulan data yang digunakan adalah observasi, wawancara berstruktur, kuesioner dan studi kepustakaan. Teknik analisis data yang digunakan adalah deskriptif kualitatif, SWOT, analisis skala sikap, dan analisis tren linear.

\section{HASIL DAN PEMBAHASAN \\ 4.1 Potensi Daya Tarik Wisata Kota Bima Sebagai Wisata Transit}

Daerah Bima mempunyai nama lain yaitu Mbojo. Nama Bima dipakai untuk mengenang dengan diabadikannya nama Sang Bima yang dinyatakan sebagai raja 
pertama. Keturunan sang Bima mempunyai hak yang sah atas atas tahta kerajaan secara turun temurun.Menurut salah satu cerita, nama Mbojo berasal dari istilah bahasa Bima "babuju” yang berarti tanah yang tinggi atau busut jantan. Tanah yang semacam itu dalam bahasa Bima disebut "dana ma mabubuju" yang dijadikan sebagai tempat pelantikan raja yang dilakukan di luar istana. Istilah itu kemudian berubah pengucapannya menjadi Mbojo.

Daerah dengan aksesibilitas sangat strategis, Kota Bima mempunyai potensi besar untuk dikembangkan menjadi Daerah Wisata Transit Alternatif. Posisi strategis tersebut menjadi peluang yang sangat besar bagi peningkatan sosial ekonomi masyarakat dan Pendapatan Asli Daerah (PAD).Sebagai suatu kawasan perkotaan, tidak banyak daya tarik wisata alam yang dimiliki oleh Kota Bima, tetapi untuk daya tarik wisata budaya potensi kepariwisataan di Kota Bima sangat besar. Hampir semua daya tarik wisata yang ada di Kota Bima belum dikemas secara menarik, padahal minat masyarakat untuk mengunjungi daya tarik wisata sangat besar. Dengan demikian upaya untuk meningkatkan mutu dan layanan daya tarik wisata di Kota Bima perlu terus dilakukan.

Kota Bima berdiri di tepi Teluk Bima yang sangat tenang. Gunung mengurungnya dan tiga penjuru (timur, utara, dan selatan). Di sepanjang pesisir Teluk Bima terdapat daya tarik wisata alam berupa Pantai Oi Mi'u, Pantai Lawata, Pantai Ule, Pantai So Ati dan Kolo, Pulau Kambing (Nisa), Areal Persawahan, dan objek wisata lainnya seperti Pantai Buncu, Dana Traha.

Kota Bima memiliki peninggalan sejarah dan kepurbakalaan yang cukup banyak. Peninggalan-peninggalan yang ada kebanyakan berasal dari masa kesultanan Bima. Daya tarik wisata budaya yang terdapat di Kota Bima antara lain: Istana Keraton Bima, Masjid Sultan Muhammad Salahuddin, Makam Dana
Traha, Makam Tolobali, Masjid Kuno Melayu, Musium Samparaja, Pasar Tradisional, Pelabuhan Bima, Sentra Kerajinan Tenun, Kampung Pandai Besi, Pacuan Kuda. Selain berbagai daya tarik tersebut di atas, masyarakat Bima juga memiliki upacara keagamaan dan kesenian yang menarik untuk dinikmati seperti: Upacara Ua Pua, Perangkat alat musik Mbojo tidak sebanyak alat musik Lombok, Bali, dan Jawa. Alat musik Mbojo terdiri atas:a). Perangkat alat musik Genda Mbojo meliputi genda (gendang, alat musik pukul), no (gong, alat musik pukul), silu dan sarone (alat musik tiup), dan katongga atau tawa-tawa sejenis no dalam ukuran kecil. Fungsi dari perangkat alat musik Genda Mbojo adalah untuk mengiringi tari; $b$ ). Biola dan gambo (gambus). Berfungsi sebagai pengiring Rawa Mbojo; c). Tambu

(tambur). Berfungsi sebagai alat musik pengiring Tari Kanja dan Sere; d). Danci (sejenis alat musik yang dibuat dari kuningan, bentuknya menyerupai mangkuk). Berfungsi sebagai pengiring Rawa Nu'a (nyanyian yang dinyanyikan oleh beberapa orang gadis. Biasanya dilakukan pada malam bulan purnama. Para penyanyi duduk membentuk lingkaran); e). Seperangkat arubana (rebana) yaitu alat musik pukul. Dipergunakan untuk menginingi hadrah. Terdiri atas tiga buah rebana yang mempunyai irama berbeda; f). Musik instrumental berupa kareku kandei yaitu alat pukul yang terdiri atas: aru (alu), kandei (lesung) dan nocu (lumpang). Biasanya dilakukan oleh para wanita dewasa dengan mengenakan sarung tradisional dengan menutupi seluruh bagian tubuhnya dan hanya kelihatan mukanya saja yang dikenal dengan rimpu.

Seni suara di Bima lebih dikenal dengan istilah rawa Mbojo. Merupakan musik tradisional Bima yang dimainkan oleh satu atau dua orang penyayi (biasanya wanita), seorang pemetik gambo (gambus), dan seorang penggesek 
biola Mbojo (biasanya laki-laki). Pemusik laki-laki terkadang merangkap sebagai penyayi. Lagu-lagu yang dibawakan berbentuk pantun nasehat, kisah mudamudi, dan humor. Selain itu Bima memiliki tarian tradisonal yang terdiri dari: 1). Tari Toja merupakan tari klasik yang tertua, 2). Tari Lenggo terdiri dari dua yaitu Tari Lenggo Melayu dan Lenggo Mbojo. Lenggo Melayu diperkenalkan oleh para mubaliq dari Pagaruyung Sumatera Barat pada masa pemerintahan Sultan Abdul Khair Sirajuddin (1640-1682). Tarian ini dibawakan oleh 4 orang remaja pria. Lenggo Mbojo diciptakan oleh Sultan Abdul Khair Sirajuddin. Penarinya terdiri atas 4 orang remaja putri. Pada saat upacara U'a Pua, kedua Tari Lenggo tersebut dipadukan terjadilah Lenggo U'a Pua. Musik pengiringnya adalah Gendang; 3). Tari Katubu adalah salah satu tari keraton (kasik) Bima yang dibawakan oleh para penari remaja yang meningkat dewasa. Tari Katubu khususnya diperagakan dalam ruangan. Musik pengiringnya adalah Genda Mbojo. Diberi nama Katubu karena irama gendang yang berbunyi "katubu"; 4). Tari Wura Bongi Monca. Tarian ini dilakukan oleh sedikitnya empat orang gadis remaja untuk menyambut kedatangan tamu pada suatu acara. 5). Buja Kadanda adalah permainan rakyat yang mempergunakan tombak yang dikreasikan dengan kadanda (bulu ekor kuda di ujung tombak). Buja berarti tombak karena itu ini dinamakan Buja Kadanda. Permainan ini sangat dinamis, penuh dengan hentakan kaki, dan teriakan pengobar semangat; 6). Hadrah adalah jenis kesenian yang bernafaskan Islam. Hadrah memadukan dua unsur seni yaitu seni suara dan seni tari. Penari yang berjumlah 4-5 orang menari dan menyanyi dengan iringan rebana. Syair yang dilantunkan berisi pujian-pujian kepada Allah, Rasul, dan para sahabat. Biasanya dipertunjukkan pada saat upacara perkawinan, khitanan, khataman AlQuran, dan menerima tamu atau pejabat yang berkunjung. 7). Gantao. Tarian ini dimainkan oleh sepasang pria dewasa yang memiliki ilmu kanuragan yang tinggi. Menunjukkan keperkasaan dan kejantanan para pemainnya. Gerak dan jurusnya sama dengan permainan silat. 8). Parise. Tarian ini mempergunakan senjata tombak dan parise (perisai). Oleh karena itu dinamakan Tari Parise. Dahulu Parise merupakan tanan persembahan kepada Sultan Bima dalam upacara kerajaan seperti perkawinan putra raja, khitanan, Maulid Nabi, pelantikan raja, dan upacara pajakai yaitu upacara memotong padi di sawah raja. Selain itu, Parise juga berfungsi sebagai tarian untuk upacara minta hujan.

\section{Lingkungan Internal dan Eksternal Kota Bima Sebagai Daerah Wisata Transit Alternatif \\ Pembangan daya tarik wisata di} Kota Bima tidak terlepas dari adanya potensi fisik dan budaya yang dimiliki Kota Bima. Perkembangan kepariwisataan di Kota Bima berdasarkan siklus hidup area pariwisata yang dikemukakan oleh Buttler (1980) berada pada tahap exploration (ekplorasi/penemuan). Pada fase ini Daerah Wisata Transit Alternatif baru mulai ditemukan dan dikunjungi oleh wisatawan dengan jumlah masih terbatas, khususnya bagi wisatawan petualang. Wisatawan yang datang berkunjung umumnya tertarik dengan pemandangan alam yang masih alami berupa pantai, pegunungan, bukit, dan sawah berundak yang belum tercemar. Pada tahap ini terjadi kontak langsung antara wisatawan dengan masyarakat lokal karena wisatawan menggunakan fasilitas lokal yang tersedia. Sehingga dampak sosial budaya dan sosial ekonomi pada tahap ini masih sangat kecil.

\section{a. Analisis Lingkungan Internal}

Rangkaian analisis lingkungan internal terlebih dahulu dilakukan dengan pembobotan faktor-faktor internal yang meliputi kekuatan dan kelemahan oleh 
para responden. Faktor-faktor kekuatan (strengths) Kota Bima meliputi: (1). posisi Kota Bima sangat strategis; (2). keanekaragaman daya tarik wisata; (3). daya tarik wisata masih alami; (4). budaya lokal yang unik; (5). keramahtamahan penduduk; dan (6). aksesibilitas menuju lokasi daya tarik wisata mudah.

Adapun yang menjadi faktorfaktor kelemahan (weaknesses) Kota Birna meliputi: (1). daya tarik wisata belum tertata baik; (2) kurangnya perhatian pernerintah pada perencanaan dan pengembangan pariwisata; (3). kualitas SDM paniwisata rendah; (4). prasarana dan sarana pariwisata yang tidak memadai; (5). promosi kurang; dan (6). rendahnya pemahaman masyarakat tentang pariwisata.

Berdasarkan analisis data tampak bahwa faktor kekuatan, khususnya posisi Kota Bima sangat strategis memperoleh bobot 0,12 yang menjadi bobot tertinggi dan Keramahtamahan penduduk memperoleh bobot 0,05 sebagai bobot terendah. Besarnya bobot posisi Kota Bima tertinggi dibandingkan dengan keramahtamahan penduduk (hospitality) yang menjadi salah sati komponen penting pariwisata karena berdasarkan atas rendahnya pemahaman responden tentang pariwisata.

Responden berpendapat bahwa perkembangan pariwisata di Kota Bima berawal dari posisi Kota Bima yang sangat strategis sehingga ditempatkan pada bobot tertinggi. Secara geografis Kota Bima sangat dekat dengan Pulau Komodo dan menjadi pintu gerbang bagi wisatawan yang mengunjungi Pulau Komodo lewat darat. Waktu tempuh jika melalui Kota Bima lebih cepat jika dibandingkan melalui Labuan Bajo di Nusa Tenggara Timur. Kota Bima juga sebagai pintu masuk arus perdagangan dari Pulau Sumbawa sebelah timur melalui pelabuhan laut sehingga menjadi pusat koleksi dan distribusi, pusat perdagangan, dan pusat pelayanan jasa. Semakin berkembangnya aktivitas perekonomian berdampak pada daya tarik Kota Bima dan sebagai Daerah Wisata Transit Alternatif juga semakin besar. Berdasarkan berbagai informasi yang dikumpulkan, kedatangan wisatawan yang transit menuju Pulau Komodo memberikan angin segar dan jalan bagi perkembangan pariwisata di Kota Bima. Pengusaha yang melihat peluang ini sebagai kegiatan yang menguntungkan mulai membangun sarana pariwisata seperti agen perjalanan, transportasi wisata, toko souvenir, akomodasi, dan rumah makan. Lokasi Kota Bima yang sangat strategis memberi dampak positif terhadap aspek promosi sehingga Kota Bima dikenal oleh wisatawan. Kota Bima mulai dikenal oleh wisatawan pertama kali karena letaknya yang strategis bukan karena keramahtamahan penduduknya. Walaupun demikian, keramahtamahan tetap menjadi hal yang penting sehingga responden menjadikan keramahtamahan sebagai salah satu kekuatan Kota Bima walaupun memperoleh bobot terendah.

Selain faktor keunikan budaya lokal, kekuatan lain yang dimiliki Kota Bima adalah keanekaragaman daya tarik wisata memperoleh bobot 0,07. Kota Bima memiiki daya tank wisata alam dan budaya yang dilengkapi dengan kesenian tradisional. Kota Bima merupakan salah satu pelabuhan alam terbaik di Indonesia yang dikelilingi oleh dataran yang subur, pemandangan alam yang indah, pantai, pulau kecil, dan goa peninggalan Jepang yang menjadi daya tarik wisata alam. Sedangkan untuk daya tarik wisata budaya berupa Istana Kesultanan Bima, situs makam, museum, pasar tradisional, sentral kerajinan tenun tradisional, pengrajin besi, dan pacuan kuda. Daya tarik wisata masih alami juga memperoleh bobot 0,07 , dimana sampai saat ini keberadaan daya tarik wisata yang ada masih alami dan belum banyak dikunjungi wisatawan sehingga mempunyai daya jual yang tinggi apabila dikemas dengan menarik. 
Keramahtamahan penduduk menduduki peningkat paling akhir untuk faktor kekuatan dengan bobot 0,05. Berdasarkan wawancara dengan wisman yang berkunjung ke Kota Bima mengatakan bahwa penduduk memiliki perilaku yang ramah dalam pergaulan, hormat dan sopan santun dalam berkomunikasi, seulas senyum selalu diberikan saat menyapa, suka memberikan pelayanan, dan sigap membantu jika wisatawan menanyakan sesuatu karena mereka dianggap sebagai tamu yang harus diperlakukan dengan baik. Walaupun Kota Bima tergolong maju namun kedatangan wisman masih dianggap sebagai hal yang aneh dan baru. Masyarakat akan berbondong-bondong mengerumuni namun tidak mengganggu. Hal tersebut justru dianggap sebagai bentuk keramahtamahan.

Kurangnya perhatian pemerintah pada perencanaan dan pengembangan pariwisata dan kualitas Sumber Daya Manusia (SDM) pariwisata rendah sangat berimplikasi terhadap faktor kelemahan berikutnya yaitu rendahnya pemahaman masyarakat tentang pariwisata dengan bobot 0,09. Rendahnya pemahaman masyarakat ini karena minimnya upaya yang dilakukan pemerintah dalam memberikan pemahaman kepada masyarakat tentang pariwisata. Kegiatan sosialisasi tidak dilakukan karena SDM pariwisata yang diharapkan mampu memberikan pemahaman kepada masyarakat sangat rendah. Masyarakat Kota Bima masih banyak yang menganggap pariwisata sebagai kegiatan yang identik dengan hura-hura dan perbuatan maksiat. Pembangunan hotel berbintang dan tempat hiburan dipersepsikan membawa dampak buruk bagi perilaku masyarakat. Inilah salah satu alasan mengapa hotel berbintang belum dibangun di Kota Bima dan tempat hiburan malam ditiadakan.

Kurangnya perhatian pemerintah pada perencanaan dan pengembangan pariwisata juga memunculkan faktor kelemahan berupa prasarana dan sarana pariwisata yang tidak memadai dengan bobot 0,08 . Pemerintah belum menjadikan sektor pariwisata sebagai skala prioritas bagi peningkatan pendapatan asli daerah. Alokasi dana untuk pembangunan fasilitas pariwisata sangat kurang dan berimphikasi terhadap minimnya fasilitas pariwisata di daya tark wisata. Di beberapa tempat seperti di Pantai Lawata dan Pantai Oi Niu pemerintah telah membangun tempat peristrahatan namun tidak terawat dengan baik. Pemerintah cenderung melakukan pembangunan tanpa melibatkan masyarakat lokal sehingga masyarakat tidak merasa memiliki. Hal ini juga diperparah dengan adanya binatang ternak yang dibiarkan berkeliaran di sekitar daya tarik wisata. Fasilitas pariwisata yang dapat dikembangkan pada daya tarik wisata misalnya pusat informasi wisata, restoran/rumah makan, kamar mandi/kamar ganti pakaian di pantai, pemandu wisata lokal, tempat penjualan cinderamata, dan penyewaan alat wisata bahari.

Kurangnya perhatian pemerintah pada perencanaan dan pengembangan pariwisata dan kualitas Sumber Daya Manusia (SDM) pariwisata rendah memunculkan kelemahan berikutnya yaitu promosi kurang yang mendapatkan bobot 0,07 . Banyak wisatawan yang belum mengetahui potensi dan keberadaan daya tarik wisata di Kota Bima. Berdasarkan realitas tersebut, kegiatan promosi yang berkelanjutan sangat penting dilakukan untuk memperkenalkan dan menarik wisatawan datang berkunjung. Wisatawan yang berkunjung kebanyakan memperoleh informasi dari agen perjalanan. Wisatawan individual yang transit menuju Pulau Komodo hanya mengetahui keberadaan Istana Bima karena letaknya yang dekat dengan pusat perbelanjaan dan tempat mereka menginap. Tempat ini juga satu-satunya di Kota Bima yang tercantum dalam brosur yang dibuat oleh Dinas 
Kebudayaan dan Pariwisata Provinsi NTB. Dinas Kebudayaan dan Pariwisata Kota Bima sendiri belum membuat bahan promosi untuk memperkenalkan keanekaragaman daya tark wisata di Kota Bima.

\section{Pemeringkatan (Rating) Lingkungan Internal}

Posisi Kota Bima sangat strategis bernilai 3,40. Posisi Kota Bima memang sangat strategis sebagai suatu Daerah Wisata Transit Alternatif karena secara geografis berlokasi dekat dengan Pulau Komodo. Faktor kedekatan inilah yang menjadikan Kota Birna sebagai tempat transit bagi wisatawan yang menuju Pulau Komodo terutama yang menggunakan jalan darat. Di ujung timur Kabupaten Bima terdapat Selat Sape yang menjadi pelabuhan penyebrangan wisatawan menuju Labuhan Bajo sebelum mereka melanjutkan perjalanannya ke Pulau Komodo. Sejak menjadi kota transit bagi wisatawan yang menuju Pulau Komodo, keberadaan Kota Bitna mulai dikenal oleh wisatawan. Wisatawan sebelum rnenyebrang ke Pulau Komodo, biasanya beristrahat sambil menikmati Kota Bima dan berbelanja untuk memenuhi kebutuhannya. Keberadaan wisatawan yang hilir mudik di Kota Bima menjadi salah satu faktor berkembangnya kepariwisataan di Kota Bima.

Faktor budaya lokal yang unik bernilai 3,20. Budaya lokal masyarakat Kota Bima hingga kini masih tetap terjaga kelestariannya. Keunikan budaya lokal yang dimiliki merupakan warisan dari Kesultanan Bima yang pernah hidup dan berkembang pada masa kerajaan dahulu. Masa kesultanan tersebut meninggalkan tradisi yang kuat dalam masyarakat yang tidak dimiliki oleh masyarakat daerah lain. Sebagian besar tradisi tersebut berlandaskan pada ajaran Agama Islam.

Faktor keanekaragarnan daya tarik wisata bernilai 3,00. Keanekaragaman daya tarik wisata di Kota Biina memang sangat bervariasi, baik daya tarik wisata alam seperti pantai, areal persawahan, perbukitan, dan pulau kecil di tengah teluk maupun daya tank wisata budaya seperti peninggalan budaya pada masa Kesultanan Bima, kesenian tradisional, dan tradisi masyarakat yang menjadi agenda budaya yang dirayakan setiap tahunnya.

Daya tarik wisata masih alami bernilai 2,83. Keadaan daya tarik wisata yang terdapat di Kota Bima sebagian besarnya masih alami dan belum mengalami perubahan yang signifikan sehingga masih menyatu dengan alam lingkungan aslinya. Disusul kemudian dengan faktor keramahtamahan penduduk menjadi dengan nilai 2,47. Cerminan sebagai tuan rumah rumah yang baik dan ramah terlihat ketika masyarakat berpapasan dengan wisatawan. Walaupun sebagian masyarakat memiliki pandangan negatif terhadap pariwisata namun wisatawan tetap dianggap sebagai tamu yang harus dihormati dan dilayani dengan baik.

Pada faktor kelemahan, kurangnya perhatian pemerintah pada perencanaan dan pengembangan pariwisata bernilai 3,10. Memang harus diakui bahwa pemerintah Kota Bima belum menjadikan pariwisata sebagai sektor utama yang diprioritaskan untuk meningkatkan PAD. Pemerintah kurang memberikan perhatian pada perencanaan dan pengembangan pariwisata sehingga memacu munculnya kelemahan-kelemahan lainnya seperti kualitas SDM pariwisata rendah dengan nilai 2,90, prasarana dan sarana pariwisata di daya tarik wisata yang tidak memadai dengan nilai 2,48 , daya tarik wisata belum tertata baik dengan nilai 2,40 , rendahnya pemahaman masyarakat tentang pariwisata dengan nilai 2,24 , dan yang terakhir yaitu promosi kurang dengan nilai 2,23 .

Tidak dapat dipungkiri bahwa SDM pariwisata di Kota Bima sangat rendah. Rendahnya kualitas SDM ini karena pemerintah belum memberikan kesempatan para pegawai pemerintah mendapatkan pendidikan dan pelatihan 
pariwisata khusus baik secara formal maupun informal. Padahal pemerintah kota bisa memanfaatkan keberadaan SMKN 1 Kota Bima untuk menambah pengetahuan dan keterampilan pegawai dalam bidang pariwisata.

Pemerintah juga tidak memberikan perhatian serius pada perbaikan prasarana dan sarana pariwisata di daya tarik wisata yang tidak memadai dan pada penataan daya tarik wisata yang kurang baik. Kalaupun diadakan perbaikan namun tidak berkelanjutan karena tidak diikuti oleh program pemeliharaan yang melibatkan masyarakat. Masyarakat memiliki pemahaman yang rendah terhadap pariwisata sehingga mernunculkan kesan negatif terhadap pariwisata dan kurangnya kesadaran masyarakat untuk .menjaga fasilitas pariwisata yang telah dibangun.

\section{b. Analisis Lingkungan Eksternal} 1. Pembobotan Lingkungan Eksternal

Rangkaian analisis lingkungan eksternal terlebih dahulu dilakukan dengan pembobotan faktor-faktor eksternal yang meliputi peluang dan ancaman oleh para responden. Faktorfaktor peluang (opportunities) Kota Bima meliputi: (1). otonomi daerah; (2). keberadaan bandara internasional di Lombok; (3). penetapan NTB sebagai destinasi unggulan; (4). kecenderungan penduduk dunia melakukan perjalanan wisata; dan (5). kemajuan teknologi, transportasi, dan telekomunikasi.

Faktor-faktor ancaman (threaths)

Kota Bima meliputi: (1). keamanan daerah NTB yang belum kondusif; (2). persaingan antar Daerah Wisata Transit Alternatif; (3). terjadinya kerusakan lingkungan yang tidak terkontrol; dan (4). dampak negatif pariwisata terhadap sosial budaya masyarakat.

Hasil angket yang diberikan kepada responden menunjukkan bahwa bobot yang diberikan masing-masing terhadap tiap indikator berbeda-beda. Untuk mendapatkan bobot yang sama pada masing-masing indikator, maka dicari rata-rata (mean) dari masingmasing indikator. Adapun pembobotan dan pemeringkatan terhadap faktor-faktor eksternal tersebut tampak pada tabel 1 . 
Tabel 1. Hasil Analisis Lingkungan Eksternal

(Eksternal Factor Analysis Strategy)

\begin{tabular}{|c|l|r|r|r|}
\hline No & \multicolumn{1}{|c|}{ Faktor } & \multicolumn{1}{|c|}{ Bobot } & \multicolumn{1}{|c|}{ Rating } & \multicolumn{1}{|c|}{ Skor } \\
\hline & \multicolumn{1}{|c|}{ Peluang } & 0,12 & 3,20 & 0,38 \\
\hline A & Otonomi daerah & 0,13 & 3,27 & 0,43 \\
\hline B & Pembukaan bandana internasional di Lombok & 0,11 & 2,40 & 0,26 \\
\hline C & Penetapan NTB sebagai destinasi unggulan & 0,12 & 3,00 & 0,36 \\
\hline D & $\begin{array}{l}\text { Kecenderungan penduduk dunia melakukan } \\
\text { perjalanan wisata }\end{array}$ & 0,15 & 3,13 & 0,47 \\
\hline E & $\begin{array}{l}\text { Kemajuan teknologi, transportasi, dan } \\
\text { telekomunikasi Ancaman }\end{array}$ & 0,04 & 1,40 & 0,06 \\
\hline F & \multicolumn{1}{|c|}{ Keamanan daerah NTB yang belum kondusif } \\
\hline G & $\begin{array}{l}\text { Persaingan antar Daerah Wisata Transit } \\
\text { Alternatif }\end{array}$ & 0,10 & 2,40 & 0,24 \\
\hline H & $\begin{array}{l}\text { Terjadinya kerusakan lingkungan yang tidak } \\
\text { terkontrol }\end{array}$ & 0,12 & 2,13 & 0,26 \\
\hline I & $\begin{array}{l}\text { Dampak negatif pariwisata terhadap sosial } \\
\text { budaya masyarakat }\end{array}$ & 0,12 & 2,00 & 0,24 \\
\hline & \multicolumn{1}{|c|}{ Total } & & $\mathbf{2 , 6 9}$ \\
\hline
\end{tabular}

Sumber: Hasil Penelitian Lapangan (2016)

\section{Pemeringkatan Lingkungan \\ Eksternal}

Pemeringkatan faktor-faktor eksternal diberikan dengan menjawab pilihan dari empat alternatif nilai yaitu tidak berpeluang, agak berpeluang, berpeluang, dan sangat berpeluang untuk faktor peluang. Untuk faktor ancaman dengan alternatif nilai yaitu tidak mengancam, agak mengancam, mengancam, dan sangat mengancam. Dari hasil pengumpulan data ternyata responden memberikan nilai yang bervaniasi. Perhitungan nilai peringkat (rating) responden didasarkan pada nilai rata-rata dari seluruh responden penelitian. Pemeringkatan para responden terlihat seperti pada Tabel 1. Adapun faktor peluang yang dimiiki Kota Bima diurutkan dari nilai tertinggi sampai terendah.

Faktor peluang tertinggi terlihat pada keberadaan bandara internasional di Lombok dengan nilai 3,27. Keberadaan bandara internasional ini memberikan angin segar bagi perkembangan pariwisata di NTB khususnya di Kota Bima, Diharapkan keberadaan bandara tersebut nantinya meningkatnya jumlah kunjungan wisatawan ke Kota Bima. Peluang berikutnya yaitu otonomi daerah dengan nilai 3,20. Hal ini sangat positif karena memberikan kesempatan kepada pemerintah Kota Bima mengembangkan potensi daya tarik wisata yang dimiliki untuk meningkatkan kesejahteraan masyarakat.

Selanjutnya adalah faktor kernajuan teknologi, transportasi, dan telekomunikasi dengan nilai 3,13. Kemajuan teknologi, transportasi, dan telekomunikasi menjadikan jarak dan waktu bukan lagi menjadi kendala bagi wisatawan dalam melakukan perjalanan. Kemajuan teknologi dan transportasi berpengaruh positif terhadap meningkatnya aksesibilitas wisatawan menuju Kota Bima. Begitupun juga dengan kemajuan telekomunikasi khususnya internet, para pelaku wisata dapat memanfaatkan media internet untuk melakukan promosi. Hal ini sangat baik karena wisatawan dari berbagai negara dapat mengakses daya tarik wisata yang terdapat di Kota Bima dengan cepat, murah, dan mudah.

Pada faktor ancaman yang memperoleh nilai tertinggi adalah 
persaingan antar Daerah Wisata Transit Alternatif dengan nilai 2,40. Besarnya nilai ini karena adanya upaya dari masingmasing Daerah Wisata Transit Alternatif khususnya Daerah Wisata Transit Alternatif terdekat seperti Bali, Lombok, dan Pulau Komodo yang telah memiliki reputasi yang bagus untuk meningkatkan jumlah kunjungan wisatawan ke daerah mereka. Berbagai upaya promosi gencar dilakukan, sarana prasarana pariwisata yang representatif disediakan, SDM ditingkatkan, daya tarik tertata dengan baik, dan pemerintah daerah memberikan stimuli bagi pengembangan daya tarik wisata sehingga pariwisata pada daerah tersebut sangat berkembang. Kondisi kepariwisataan Kota Bima yang baru mulai dikembangkan, tentu saja persaingan yang dilakukan antar Daerah Wisata Transit Alternatif menjadi ancaman serius. Menyadari hal tersebut, sudah sepatutnya para stakeholders pariwisata di Kota Bima mulai mengembangkan daya tarik yang spesifik agar lebih unggul dibandingkan dengan pesaingnya.

Faktor terjadinya kerusakan lingkungan yang tidak terkontrol memperoleh nilai 2,13 dan dampak negatif pariwisata terhadap sosial budaya masyarakat memperoleh nilai 2,00. Perkembangan pariwisata tidak selamanya memberikan kontribusi positif bagi kemaslahatan hidup manusia. Kurangnya perencanaan dan rendahnya perhatian para stakeholders terhadap pariwisata yang berkelanjutan menimbulkan dampak negatif paniwisata terhadap lingkungan dan sosial budaya masyarakat. Ini menjadi ancaman bagi pengembangan pariwisata Kota Bima.
Ancaman ini semakin mengkhawatirkan mengingat kurangnya perhatian pemerintah Kota Bima dalam perencanaan dan pengembangan pariwisata, rendahnya kualitas SDM, dan rendahnya pemaharnan masyarakat terhadap pariwisata. Bila ancaman ini terus terjadi maka pengembangan pariwisata di Kota Bima tidak akan rnembuahkan hasil yang optimal.

2Strategi Umum Pengembangan Kota Bima Sebagai Daerah Wisata Transit Alternatif

Berdasarkan hasil analisis lingkungan internal dan eksternal pada Kota Bima, maka posisi lingkungan internal Kota Bima berada pada posisi yang kuat dengan nilai yang diperoleh 2,84 dan posisi lingkungan eksternal Kota Bima berada pada posisi yang kuat dengan nilai yang diperoleh 2,69. Untuk mengetahui strategi pergembangan Kota Bima sebagai Daerah Wisata Transit Alternatif maka nilai dari analisis lingkungan internal dan eksternal dituangkan dalam matrik InternalEksternal sebagaimana terlihat pada Tabel 5.3.

$\begin{array}{rcr}\text { Berdasarkan } & \text { Tabel } 2 & \text { dapat } \\ \text { diketahui bahwa } & \text { strategi } & \text { umum }\end{array}$
pengembangan Kota Bima ada pada sel V, yakni strategi konsentrasi melalui integrasi horisontal dan tidak ada perubahan profit strategi dimana kawasan yang berada dalam kondisi ini dapat memperluas pasar, fasilitas produksi dan teknologi melalui pengembangan internal dan eksternal. Strategi umum pengembangan Kota Bima adalah strategi penetrasi pasar dan pengembangan produk. 
Tabel 2 Matrik Internal-Ekstemal Kota Bima

TOTAL NILAI IFE

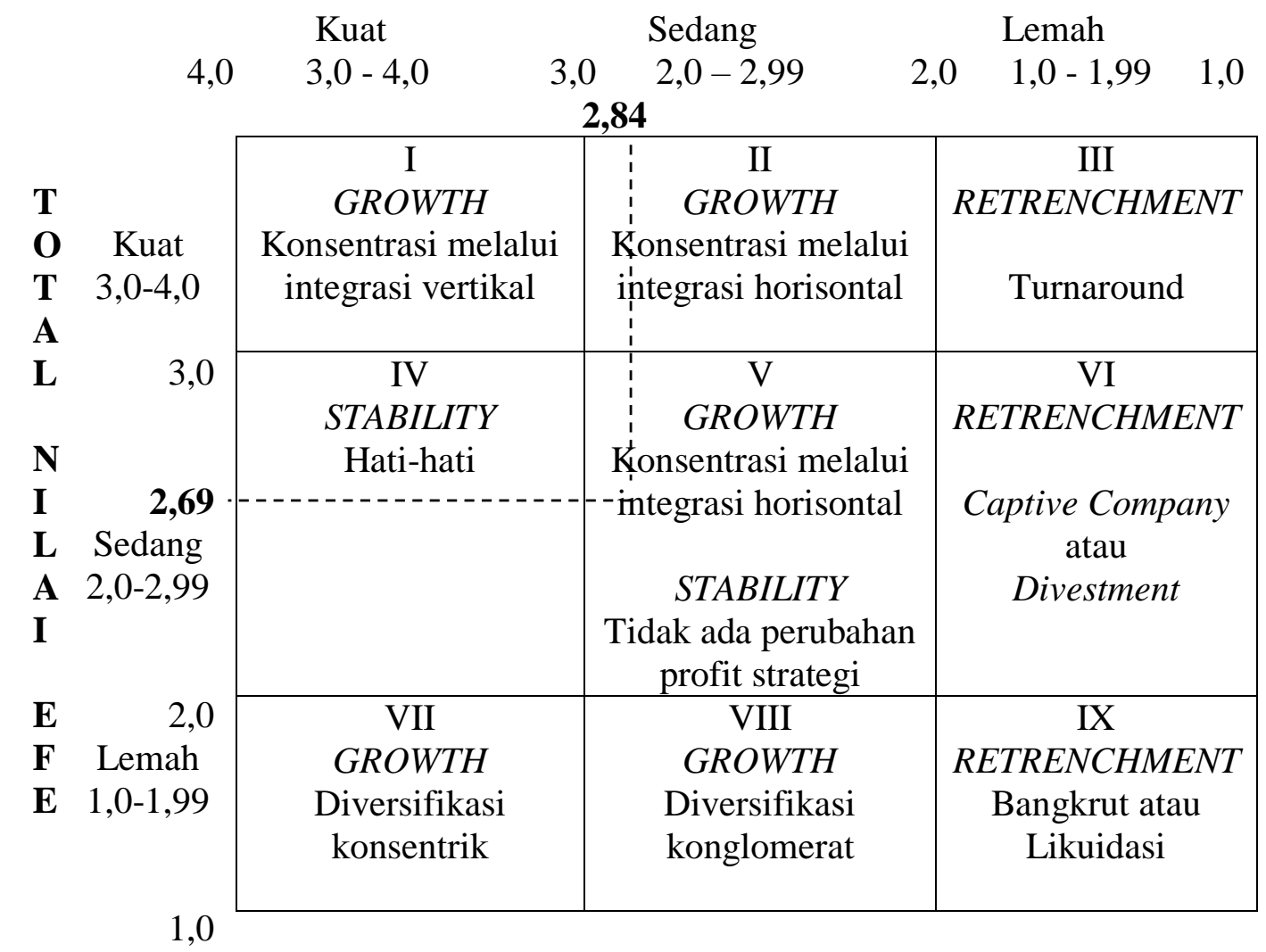

Strategi penetrasi pasar dimaksudkan dengan mencari pangsa pasar yang lebih besar untuk produk atau jasa yang sudah ada melalui usaha pemasaran yang lebih gencar ke berbagai pasar wisatawan seperti ke kawasan Amerika, Eropa, Asia, dan Timur Tengah atau memanfaatkan potensi wisatawan nusantara dan wisatawan lokal. Sedangkan strategi pengembangan produk yaitu meningkatkan penjualan dengan membuat kebijakan tentang kepariwisataan dan memperbaiki penataan daya tarik wisata yang sudah ada misalnya dengan pemanfaatan areal persawahan dan perbukitan untuk areal tracking, pengembangan agrowisata groso, pengembangan produk wisata bahari dengan pemanfaatan wilayah Teluk Bima, dan menjual fasilitas olahraga. Dari aspek budaya, Kota Bima memiliki berbagai jenis atraksi budaya seperti budaya rimpu, perayaan Ua Pua, dan kesenian lokal agar lebih diperkenalkan lagi kepada wisatawan.

\section{Strategi Alternatif Pengembangan Kota Bima Sebagai Daerah Wisata Transit Alternatif \\ Berdasarkan kekuatan dan} kelemahan pengembangan Kota Bima sebagai Daerah Wisata Transit Alternatif, maka rnelalui analisis SWOT akan ditemukan strategi pengembangan yang dapat mendukung kelayakan daya tarik wisata seperti terlihat pada Tabel 3 . Kemudian berdasarkan analisis SWOT tersebut disusun alternatif pengembangan daya tarik sebagai strategi alternatif yang merupakan opsi pengembangan dari strategi umurn.

Adapun strategi alternatif yang akan digunakan dalam pengembangan Kota Bima sebagai Daerah Wisata Transit Alternatif terdiri atas:

1. Strategi SO

Merupakan menggunakan memanfaatkan menghasilkan: 
pengembangan daya tarik wisata di Kota Bima.

2. Strategi ST

Merupakan strategi yang menggunakan kekuatan untuk mengatasi ancaman, menghasilkan:

(1) strategi peningkatan keamanan.

3. Strategi WO

Merupakan strategi yang

meminimalkan kelemahan untuk

memanfaatkan

menghasilkan:

pengembangan

sarana pariwisata dan (2) strategi penetrasi pasar dan promosi daya tarik wisata di Kota Bima.

4. Strategi WT

Merupakan strategi yang meminimalkan kelemahan dan menghindari ancaman, menghasilkan: (1) strategi perencanaan dan pengembangan pariwisata berkelanjutan dan berbasis kerakyatan dan (2) strategi pengembangan kelembagaan dan SDM panwisata.

Tabel 3. Analisis SWOT Pengembangan Kota Bima Sebagai Daerah Wisata Transit Alternatif

\begin{tabular}{|c|c|c|}
\hline & Kekuatan (Strengths) & Kelemahan (Weaknesses) \\
\hline Faktor Internal & $\begin{array}{l}\text { 1. Posisi Kota Bima } \\
\text { sangat strategis. } \\
\text { 2. Keanekaragaman } \\
\text { daya tarik wisata. } \\
\text { 3. Daya tarikwisata } \\
\text { masih alami. } \\
\text { 4. Budaya lokal yang } \\
\text { unik. } \\
\text { 5. Keramahtamahan } \\
\text { penduduk. } \\
\text { 6. Aksesibilitas } \\
\text { menuju lokasi daya } \\
\text { tarik wisata mudah. }\end{array}$ & $\begin{array}{l}\text { 1. Daya tarik wisata belum tertata } \\
\text { baik. } \\
\text { 2. Kurangnya perhatian pemerintah } \\
\text { pada perencanaan dan } \\
\text { pengembangan pariwisata } \\
\text { 3. Kualitas SDM pariwisata } \\
\text { rendah. } \\
\text { 4. Prasarana dan sarana pariwisata } \\
\text { yang tidak memadai. } \\
\text { 5. Promosi kurang. } \\
\text { 6. Rendahnya pemahaman } \\
\text { masyarakat tentang pariwisata. }\end{array}$ \\
\hline \multicolumn{3}{|l|}{ Faktor Eksternal } \\
\hline $\begin{array}{l}\text { Peluang } \\
\text { (Opportunities) }\end{array}$ & $\begin{array}{c}\text { Strategi SO } \\
\text { (Strengths } \\
\text { Opportunities) } \\
\end{array}$ & $\begin{array}{c}\text { Strategi WO } \\
\text { (Weaknesses Opportunities) }\end{array}$ \\
\hline $\begin{array}{l}\text { 1. Otonomi daerah. } \\
\text { 2. Keberadaan bandara } \\
\text { internasional di } \\
\text { Lombok. }\end{array}$ & $\begin{array}{c}\text { Menggunakan kekuatan } \\
\text { untuk memanfaatkan } \\
\text { peluang }\end{array}$ & $\begin{array}{c}\text { Meminimalkan kelemahan } \\
\text { untuk memanfaatkan } \\
\text { peluang }\end{array}$ \\
\hline $\begin{array}{l}\text { 3. Penetapan NTB } \\
\text { sebagai destinasi } \\
\text { unggulan. } \\
\text { 4. Kecenderungan }\end{array}$ & $\begin{array}{c}\text { Strategi } \\
\text { pengembangan } \\
\text { daya tarik wisata di } \\
\text { Kota Bima }\end{array}$ & $\begin{array}{c}\text { Strategi pengembangan } \\
\text { prasarana dan sarana } \\
\text { pariwisata }\end{array}$ \\
\hline $\begin{array}{l}\text { penduduk dunia } \\
\text { melakukan } \\
\text { perjalanan wisata. } \\
\text { 5. Kemajuan teknologi, } \\
\text { transportasi, dan } \\
\text { telekomunikasi. }\end{array}$ & & $\begin{array}{c}\text { Strategi penetrasi pasar } \\
\text { dan promosi daya tarik } \\
\text { wisata }\end{array}$ \\
\hline Ancaman (Threats) & Strategi ST & Strategi WT \\
\hline
\end{tabular}




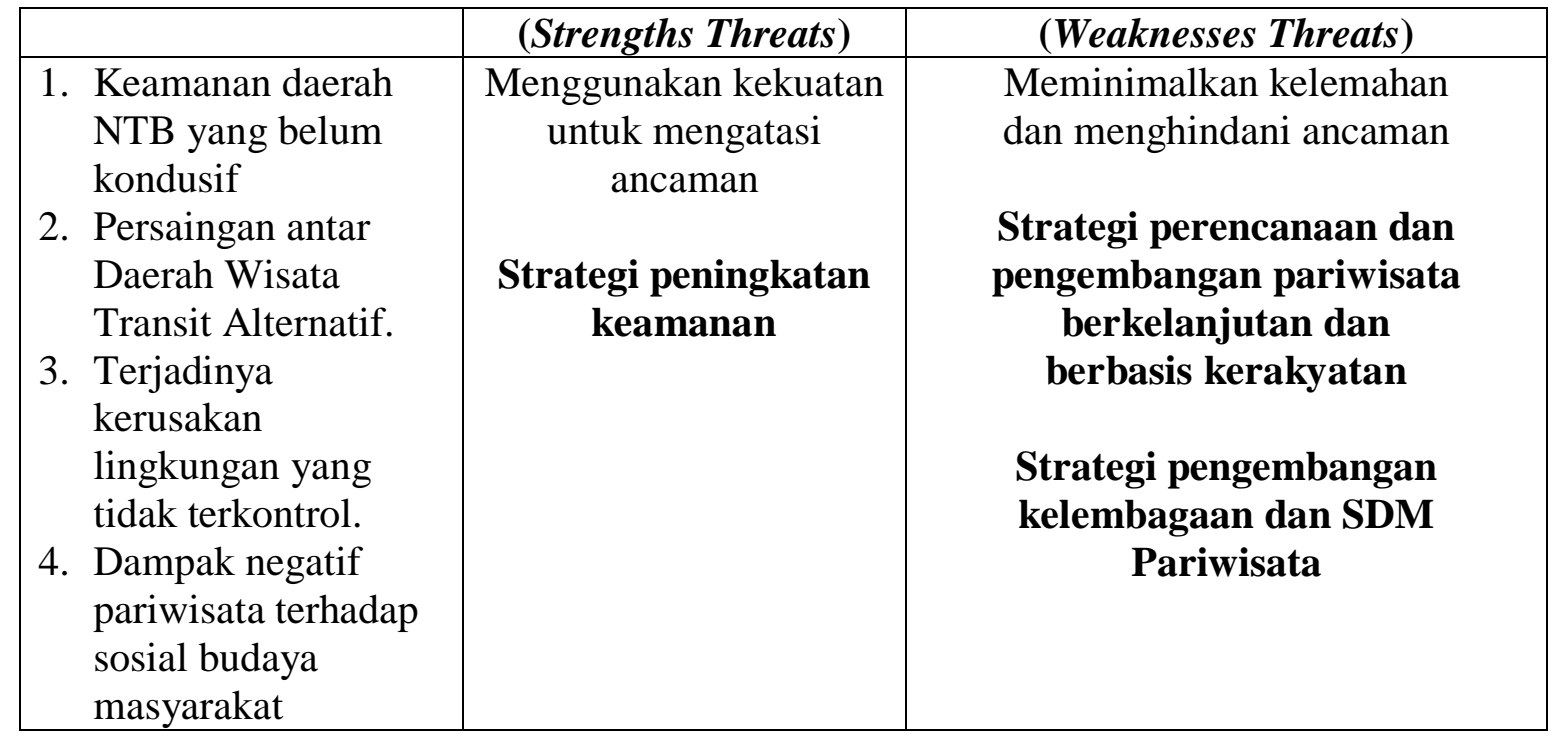

Sumber: Hasil penelitian lapangan, 2016

\section{KESIMPULAN DAN SARAN}

Berdasarkan penelitian strategi pengembangan Kota Bima sebagai daerah tujuan wisata dapat disimpulkan sebagai berikut:

1. Sarana dan prasarana pariwisata di Kota Bima meliputi sarana kesehatan, transportasi, air bersih, energi, perbankan, pos, telekomunikasi, dan usaha sarana dan jasa pariwisata. Potensi daya tarik wisata di Kota Bima meliputi: daya tarik wisata alam yang terdiri atas: Pantai Oi Niu, Pantai Lawata, Pantai Ule, Pantai So Au, Pulau Kambing, dan areal persawahan. Daya tarik wisata budaya terdiri atas: Istana Bima, Masjid Sultan M. Salahuddin, Makam Danataraha, Makam Tolobali, Masjid Kuno Melayu, Museum Samparaja, pasar tradisional, Pelabuhan Bima, kampung pandai besi, pacuan kuda, dan upacara dan kesenian seperti Upacara U'a Pua, seni musik, seni suara, Tari Toja, Tari Lenggo, Tari Katubu, Tari Wura Bongi Monca, Buja Kadanda, Hadrah, Gantao, dan Parise.

2. Strategi pengembangan Kota Bima sebaga kota transit wisata alternatif terdiri atas strategi umum dan strategi alternatif. Strategi umum meliputi: strategi penetrasi pasar dan pengembangan produk wisata. Adapun strategi alternatif meliputi: pengembangan daya tarik wisata di Kota Bima, peningkatan keamanan, pengembangan prasarana dan sarana pariwisata, promosi daya, perencanaan dan pengembangan pariwisata berkelanjutan dan berbasis kerakyatan, serta pengembangan kelembagaan dan SDM pariwisata.

3. Program-program yang dirancang untuk pengembangan Kota Bima sebagai daerah tujuan wisata meliputi: program penyusunan blok kawasan, program pengembangan produk wisata, program inventarisasi daya tarik wisata, program peningkatan keamanan melalui Sistem Keamanan Lingkungan (Siskamling), pembangunan hotel berbintang, meningkatkan akses ke Kawasan Kolo, rencana pengembangan sarana wisata tirta, penyediaan fasilitas toilet dan kamar mandi umum, penyediaan ruang terbuka (open space), rencana pengembangan jalur tracking, memperluas pangsa pasar, melakukan promosi melalui Biro 
Perjalanan Wisata, melakukan promosi melalui internet dan media lainnya, mendirikan TIC (Tourism Information Centre), melaksanakan pentas kebudayaan, menjaga kelestarian lingkungan, pelestarian nilai sosial budaya, pemberdayaan masyarakat, membentuk lembaga pengelolaan daya tarik wisata, meningkatkan kualitas SDM pariwisata, serta mengadakan kampanye sadar wisata dan sosialisasi sapta pesona.

\subsection{Saran}

Berdasarkan kelemahan dan ancaman yang dimiliki Kota Bima dalam upaya pengembangannya sebagai daerah tujuan wisata, maka dapat disarankan beberapa hal sebagai berikut:

1. Pemerintah Kota harus memberikan priontas dalam pembangunan yang berhubungan dengan prasarana dan sarana air bersih, energi listrik, dan sarana pariwisata yang dirasakan masih kurang seperti hotel berbintang dan fasilitas pariwisata di daya tarik wisata.

2. Pemerintah berusaha meningkatkan jumlah pangsa pasar melalui usaha pemasaran yang lebih intensif untuk menyasar pasar potensial seperti pasar Asia, Timur Tengah, dan menggarap pangsa pasar nusantara melalui biro perjalanan wisata. Selain itu, Pemerintah juga harus meningkatkan jenis produk wisata yang ada agar menarik lebih banyak wisatawan mengunjunginya.

3. Kepada seluruh stakeholder pariwisata Kota Bima agar sedapat mungkin menjalankan programprogram yang telah dirancang untuk menyongsong pengembangan Kota Bima sebagai daerah tujuan wisata.

\section{DAFTAR PUSTAKA}

Assauri, 1987. Manajemen Pemasaran: Dasar Konsep dan Strategi. Jakarta: Rajawali Pers

Haryono. 2003. Potensi Taman Nasional Baluran Sebagai Objek Wisata Alam di Kabupaten Situbondo. Jember: Penelitian Dikti Akademi Pariwisata Muhammadiyah Jember.

Juhanda. 2003. Sumberdaya Manusia Lembaga Dan Pemberdayaan Masyarakat Pariwisata di Kabupaten Bondowoso. Kantor Pariwisata, Seni dan Budaya Kabupaten Bondowoso.

Kotler, Philip. 1993. Marketing Places: Attracting Invesment, Industry and Tourism to Cities,States and Nations. The Free Press, New York.

Pendit, Nyoman S. 1990, Ilmu Pariwisata Sebuah PengantarPerdana. Jakarta: Pradnya Paramita.

Pusat Studi Pariwisata Universitas Gadjah Mada. 2003. Rencana Induk Pengembanga Pariwisata Daerah (RIPPDA) Kabupaten Sumba Barat . Jogyakarta.

Singarimbun, 1989. Metode Penelitian Survey. Jakarta: Gramedia.

Setiawan, 2004. Peranan Partisipasi Masyarakat Sumber Rejo Dalam Kegiatan Pariwisata di Objek wisata Pantai Watu Ulo Kabupaten Jember. Jember: AKPAR Muhammadiyah Jember.

Sirajuddin. 2004. Prospek Pengembangan Objek Wisata Gunung Rembangan Sebagai Objek wisata Alam di Kabupaten Jember. Jember: AKPAR Muhammadiyah Jember.

Undang - Undang Otonomi Daerah. 1999. Bandung: Citra Umbara . 
Wahyudi, 2003. Prospek Pengembangan Kawah Ijen Sebagai Objek Wisata Alam di Kabupaten Situbondo. Jember: Penelitian Dikti Akademi Pariwisata Muhammadiyah Jember.
World Tourism Organization (WTO).1998.

GuideforLocalAuthoritiesonDevelo pingSustainableTourism. ---- WTO

Yoeti, Oka, 1997, Perencanaan dan Pengembangan Pariwisata. Jakarta: Pradnya Paramita 